\title{
Modelling of orographic precipitation over Iberia: a springtime case study
}

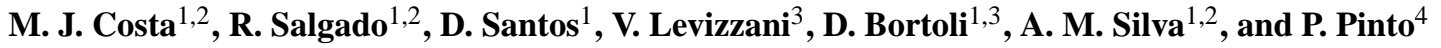 \\ ${ }^{1}$ Évora Geophysics Centre, University of Évora, Évora, Portugal \\ ${ }^{2}$ Physics Department, University of Évora, Évora, Portugal \\ ${ }^{3}$ Institute of Atmospheric Sciences and Climate, ISAC-CNR, Bologna, Italy \\ ${ }^{4}$ Meteorological Institute of Portugal, Lisboa, Portugal
}

Received: 2 November 2009 - Revised: 12 April 2010 - Accepted: 13 April 2010 - Published: 7 May 2010

\begin{abstract}
Orographic precipitation is a result of very complex processes and its study using numerical models is of utmost importance since it can open an important avenue to the improvement of precipitation forecasts, especially during the warm season. Mainland Portugal is characterised by a very variable terrain between the north and south regions, the latter being much smoother, with sparse mountains that barely reach $1000 \mathrm{~m}$. Conversely, several mountain ranges are distributed over Spain with heights often exceeding $1500 \mathrm{~m}$ altitude. A mesoscale non-hydrostatic atmospheric model (MesoNH) is used to study the orographic precipitation during a limited period in spring of 2002 over the Iberian Peninsula. In order to assess the effects of the mountains, case study simulations are done, with and without the orography. MesoNH is initialized and forced by the ECMWF analyses. The effects of orography on precipitation over neighbouring regions are also analyzed. Simulations show that orography is a key factor in determining the spatial distribution of precipitation over the Iberian Peninsula, with enhancements in the regions with mountain ranges and diminution or suppression over certain valleys. The simulated precipitation fields were visually compared with radar observations in central Portugal and quantitatively compared with rain gauge data all over Portugal in order to assess the model performance in the analyzed cases.
\end{abstract}

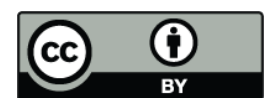

Correspondence to: M. J. Costa (mjcosta@uevora.pt)

\section{Introduction}

The northern and eastern regions of the Iberian Peninsula can be distinguished from the south-western parts by their higher altitudes and steep terrain relief. South-western Iberia is characterised by lower altitudes, predominantly flat hills, apart from a few exceptions of mountain ranges reaching up to $1000 \mathrm{~m}$. The annual precipitation distribution over the region is uneven as well, being more abundant on the northern and eastern regions partially due to orographic precipitation. In the south-western regions, precipitation is usually scarcer, with a few exceptions observed over the mountains.

The late spring atmospheric circulation over Iberia is mainly determined by (1) the location, intensity and pattern of the Azores high pressure system, (2) the existence, location and intensity of a thermal low pressure system over the Peninsula, and (3) the passage of the very last polar fronts, very common in the beginning of springtime. The Iberian thermal low may be intended as the organisation of an assembly of circulation cells from sea and valley breezes, as well as from lower scale convection, instead of a unique low with a well defined centre, whose convective cells grow and interact during the day, originating in the afternoon a well organised circulation at the peninsular scale (Millán et al., 2000). In summer, the sea breeze can penetrate several tenths of kilometres inland (Millán et al., 1991), incorporating upslope circulation cells on its way towards the inner regions and thus integrating the Iberian thermal depression. The development of the thermal low amplifies the convergence effect of surface winds that blow from the sea and from the valleys (upslope winds). As a result, from the end of spring and onwards, the Iberian climatology is largely explained by the atmospheric circulation dynamics forced by the thermal land-sea

Published by Copernicus Publications on behalf of the European Geosciences Union. 
and mountain/valley contrasts at the peninsular scale, which condition the transport of pollutants and the precipitation regime.

The problem of providing effective weather forecasts in this complex context is an extremely challenging issue. More generally, the quantitative precipitation forecast over complex topography is still a matter of concern (Roe, 2005; Hohenegger and Schär, 2007; Argence et al., 2009). The use of atmospheric models and the evaluation of simulation results are essential in view of prospective improvements of precipitation forecasts. This is the reason behind fundamental research studies on organised convection, especially in the warm season (May-August); observations with radar and satellites have allowed a first understanding of the generation and propagation mechanisms (Laing et al., 2008; Keenan and Carbone, 2008) as well as for the development of warm season precipitation climatologies (Carbone et al., 2002; Wang et al., 2004, 2005; Levizzani et al., 2006). The theoretical framework related to the interpretation of orographic precipitation patterns can be found, among others, in Smith and Barstad (2004) and Rotunno and Houze (2007). Carbone and Tuttle (2008) confirmed the role of propagating rainfall systems and the high frequency at which these are excited by sensible heating over elevated terrain. A comparison of satellite-derived rainfall rates and model forecasts during the North America Monsoon Experiment (NAME) (Janowiak et al., 2007) showed that the models tend to overforecast the frequency of rainfall events in the $1-75 \mathrm{~mm} \mathrm{day}^{-1}$ range and underforecast heavy rain events $\left(>85 \mathrm{~mm} \mathrm{day}^{-1}\right)$.

The present study aims at assessing the effects of orography over the Iberian Peninsula, for a late spring case study, lasting 20 days. For this purpose, a mesoscale, nonhydrostatic atmospheric model is used, to simulate precipitation occurrence considering the actual ground relief over Iberia. The reference case is simulated over a completely flat terrain.

Section 2 reports the model setup and the methods used for the study, Sect. 3 presents the results and discussion, and a summary is the subject of Sect. 4 .

\section{Model setup and method}

The mesoscale, non-hydrostatic atmospheric model MesoNH (Lafore et al., 1998) was used to simulate the orographic precipitation during a short period in spring 2002, over the mountain ranges of mainland Portugal and Spain.

The turbulent scheme is based on a one-dimensional 1.5 closure, using the Bougeault and Lacarrère (1989) mixing length. The model configuration included the mixed microphysical scheme for stratiform clouds and explicit precipitation (Cohard and Pinty, 2000), which distinguishes six classes of hydrometeors (water vapour, cloud water, liquid water, ice, snow, and graupel). The Kain-Fritsch

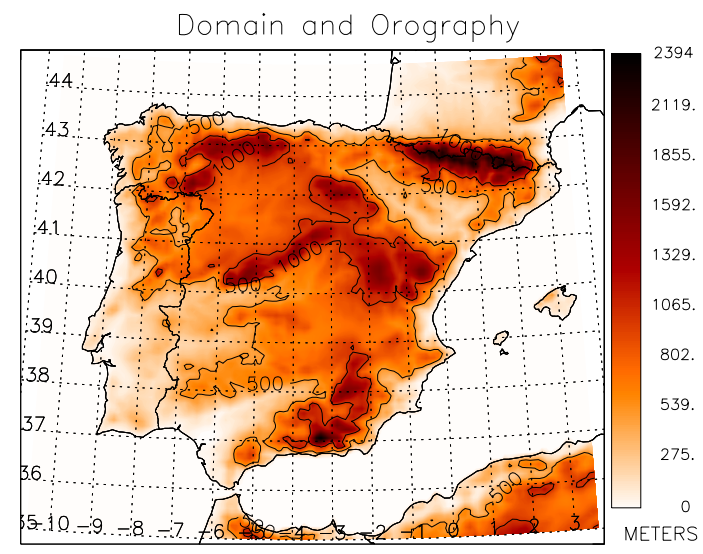

Fig. 1. Geographic domain and orography.

convection scheme type was activated (Bechtold et al., 2001). The MesoNH radiation scheme treats successively the longwave and shortwave radiative transfer equations for independent air columns (Morcrette, 1991; ECMWF, 2009). The exchange flux between the atmosphere and the surface was taken into account using physical parameterisations: the surface soil and vegetation are described by the Interface Soil Biosphere Atmosphere (ISBA) model (Noilhan and Mahfouf, 1996); the town energy balance was handled according to Masson (2000); the water surface evolution was represented by the FLake model (Mironov, 2008) linked to the MesoNH system by Salgado and Le Moigne (2010). The orography was obtained from the GTOPO30 database (http://eros.usgs.gov/ \#/Find_Data/Products_and_Data_Available/gtopo30_info, access: 2 September 2009) and the land cover was taken from the ECOCLIMAP database (Masson et al., 2003).

The numerical simulations were performed for the period starting on 30 May 2002, 00:00 UTC, until 20 June 2002, 00:00 UTC. The geographical domain is shown in Fig. 1 spanning $1215 \times 1080 \mathrm{~km}^{2}$, with a spatial resolution of $9 \times 9 \mathrm{~km}^{2}$ (16200 horizontal grid points). As for the vertical resolution, 45 stretched levels were considered, from $10 \mathrm{~m}$ to $26 \mathrm{~km}$. The MesoNH was initialised and forced by the European Centre for Medium-Range Weather Forecasts (ECMWF) analyses, updated every six hours. The numerical simulations were divided into seven segments of three days, each segment being initialized from the large-scale analysis at 18:00 UTC of the previous day. The first six hour run was used as the spin-up period.

In order to assess the effects of orography on the precipitation fields, a set of two numerical simulations were performed, one with the real orography (shown in Fig. 1) and another serving as reference, with the orography set to zero. The precipitation differences, between the simulations with and without orography, were then computed, with the aim of evaluating the effect of terrain relief on Iberia's total precipitation, during the study period. 

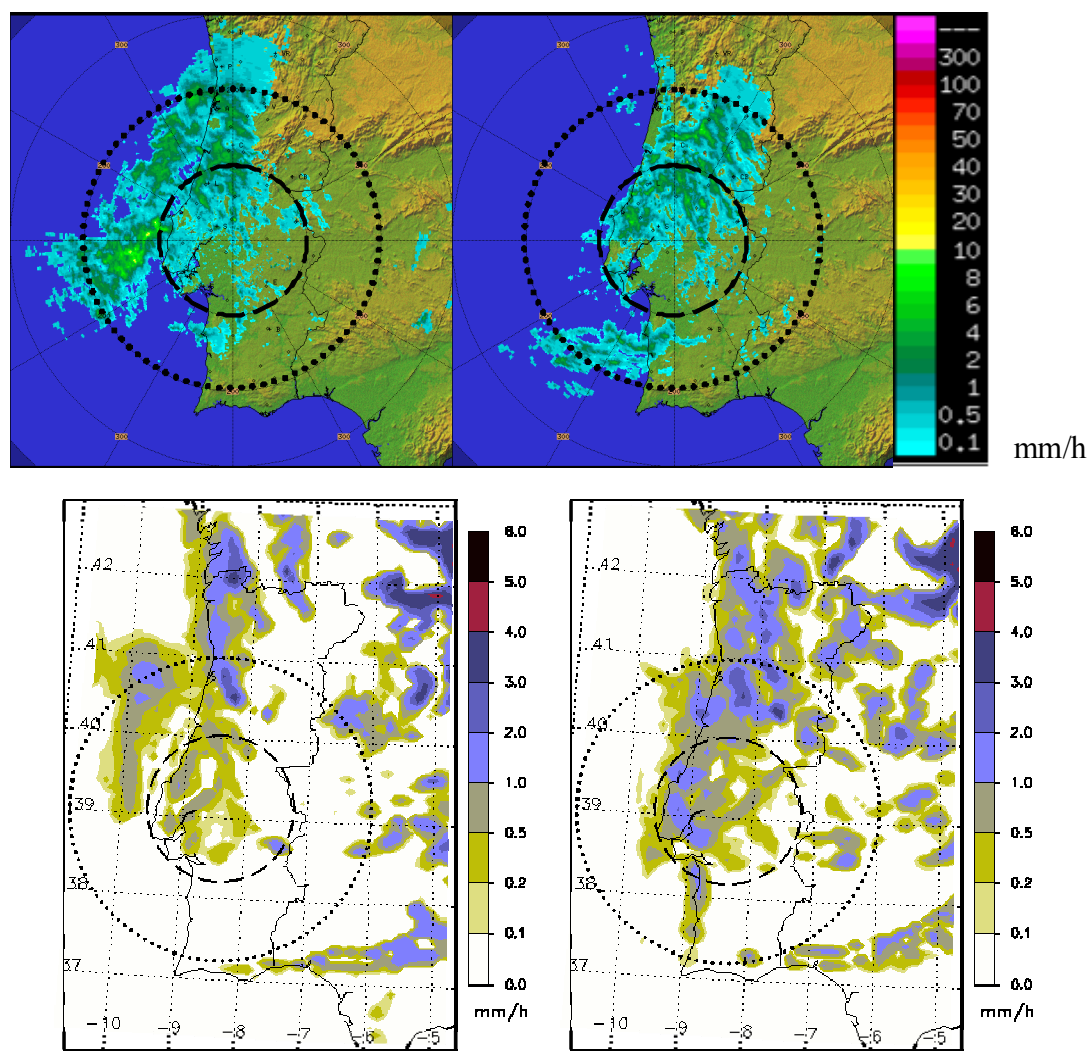

Fig. 2. Rainfall rate, in $\mathrm{mm} \mathrm{h}^{-1}$, obtained from the $\mathrm{C}$ band Doppler radar measurements (upper panels) and corresponding modelling results (lower panels), on 4 June 2002 at 14:00 UTC (left) and 16:00 UTC (right). The dashed and dotted circles, delimit the 100 and $200 \mathrm{~km}$ radar range, respectively.

\section{Results and discussion}

\subsection{Visual qualitative comparison with radar data}

The scans of the C-band Doppler radar of the Meteorological Institute of Portugal, installed in Coruche/Cruz de Leão are used in comparison with the model precipitation fields. However, this comparison between radar and model fields was hindered by the need for a radar dataset reasonably free from ground clutter, which was not the case of the period under examination. The complex orography of Portugal suggests that the quality of the observed precipitation fields was not satisfactory without reasonable clutter suppression and thus a quantitative comparison was not carried out.

Figure 2 shows the radar precipitation rate (upper panels), as well as the corresponding model results (lower panels), on 4 June 2002, 14:00 UTC (left) and 16:00 UTC (right). The radar is installed in the centre of Portugal (see intersection of lines in Fig. 2) and the observations are considered adequate to qualitatively represent the precipitation at the surface. The rainfall field used in the comparison is the one within a $200 \mathrm{~km}$ range from the radar location (circle enclosed by the dotted line in Fig. 2). The range of $200 \mathrm{~km}$ from the radar station seems to be acceptable to obtain quali- tative rainfall estimates, according to the low elevations used in the radar scanning from which the precipitation fields were derived and to the average ground elevation in the area (in general, higher than the radar station ground). The adopted $\mathrm{Z}-\mathrm{R}$ relationship was the modified Marshall-Palmer: $\mathrm{Z}=200$ $\mathrm{R}^{1.6}$; the nominal Cartesian spatial resolution is $1 \mathrm{~km} \times 1 \mathrm{~km}$, while the real polar resolution, assuming a radial integration over $1 \mathrm{~km}$, can be considered to be somewhere between $1 \mathrm{~km} \times 0.85 \mathrm{~km}$ at $100 \mathrm{~km}$ range and $1 \mathrm{~km} \times 1.7 \mathrm{~km}$ at $200 \mathrm{~km}$ range.

The two datasets (radar and model) have different spatial resolutions. However, the main patterns observed by the radar are also present in the model results. The rainfall registered by the radar at 14:00 UTC over the Atlantic Ocean along the central and northern Portuguese coast and moving inland is well reproduced by the model. The shift of the precipitation system inland at 16:00 UTC is also well captured by the MesoNH results. The rainfall reported by the model inland and to the far north are out of the radar coverage deemed suitable for describing the measured surface precipitation field (radar range $>200 \mathrm{~km}$ ). 

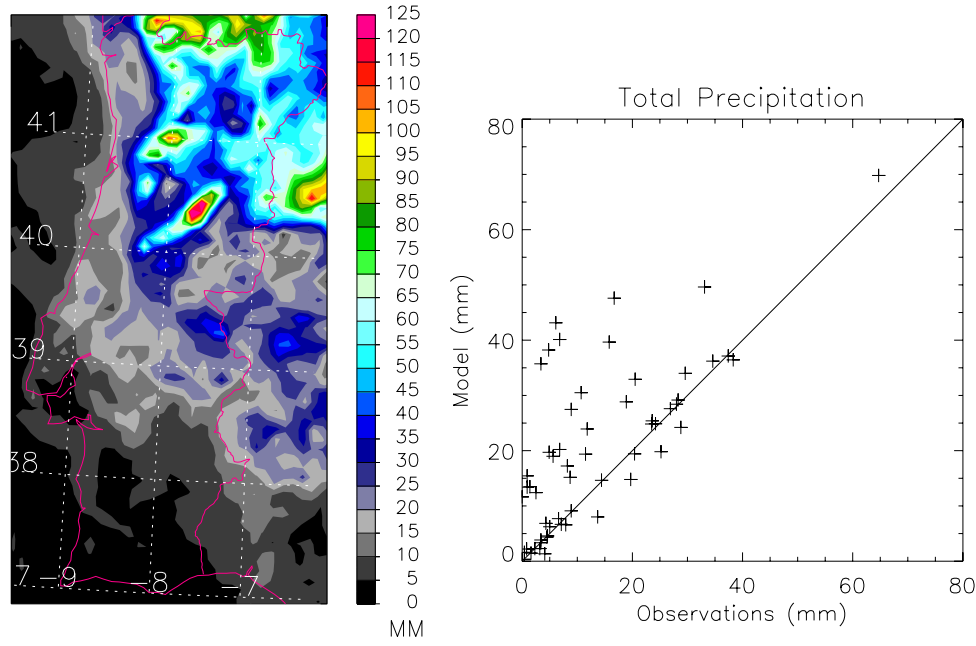

Fig. 3. Accumulated precipitation, in mm, from 30 May to 20 June 2002 obtained from the simulations (left) and scatter plot of the total accumulated precipitation rain gauge measurements versus model data at the nearest grid point (right).

A qualitative comparison of model and radar precipitation fields shows that in general the model reproduces the precipitation observations reasonably well. The MesoNH ability of simulating precipitation over complex terrain relief has already been reported in the literature, in particular by Argence et al. (2009), and thus it seems an appropriate tool for assessing the role of orography on the precipitation regime. Since the clutter removal mechanism is now in place and the model has shown reasonable skills in predicting orographic effects on the precipitation field, quantitative comparisons will be performed in the future with a suitable radar-model dataset.

\subsection{Comparison with rain gauge data}

The model results are compared with rain gauge data from the rain gauge network of the Meteorological Institute of Portugal. Hourly values of the accumulated precipitation for a total of 57 meteorological stations are used. Figure 3 (left) shows the spatial distribution of the accumulated precipitation, from 30 May to 20 June 2002, obtained from the MesoNH simulations and on the right panel a scatter plot of rain gauge versus model data is presented. The comparison between the modelled accumulated precipitation spatial distribution and the interpolated rain gauge data map (not shown here), shows that the model reproduces the main precipitation distribution features. The higher values of rainfall measurements in the centre and north of Portugal (Fig. 3 left) are also present in the rain gauge measurements. Similarly, there is accordance for the lower precipitation amounts in the south of the country. Nevertheless, it is noticeable from the scatter plot of rain gauge versus model data (Fig. 3 right) that the model tends to overestimate rainfall, when compared to the rain gauge data. This may be partly connected with the fact that the spatial resolution of the rain gauge data (mean distance between the rain gauges of $28 \mathrm{~km}$ ) is much lower than the model grid (spatial resolution of $9 \times 9 \mathrm{~km}^{2}$ ) and often there are no rain gauges in the positions where the model reports maximum precipitation values. The model grid point spatially closest to the rain gauge location is taken as the corresponding value to build up each model - observational pair. The correlation coefficient between modelled and observational accumulated rainfall for the whole period was computed for all the 57 model - observation pairs obtaining a value of 0.71 , which reveals the fairly good agreement between model and observational data for the whole period of study.

A quantitative comparison between modelling results and rain gauge data is performed through the evaluation of traditional statistical skill scores such as the equitable threat score (ETS) and the bias score (BS). The ETS gives a measure of the event forecast accuracy, in this case rainfall occurrence above a certain threshold, within a certain time frame (typically six hours for mesoscale modelling). It is defined by Schaefer (1990) as:

$$
\mathrm{ETS}=\frac{\mathrm{N}_{c}-\mathrm{E}}{\mathrm{N}_{p}+\mathrm{N}_{o}-\mathrm{N}_{c}-\mathrm{E}}
$$

where $\mathrm{N}_{c}$ represents the number of stations where the modelled rainfall intensity above a certain threshold is correct, $\mathrm{N}_{p}$ the number of station modelled values above the threshold, and $\mathrm{N}_{o}$ the number of stations observing an amount of rainfall above the same threshold. $\mathrm{E}$ is given by $\left(\mathrm{N}_{p} \mathrm{~N}_{o}\right) / \mathrm{N}$, representing the number of random correct modelled expected values due to chance within the total number $\mathrm{N}$ of model and observational pairs.

The BS measures the tendency of a model to estimate too large or too small an area of a given amount of precipitation. For the discrete case this score is defined as (Anthes, 1983):

$\mathrm{BS}=\frac{\mathrm{N}_{p}}{\mathrm{~N}_{o}}$ 
Table 1. Values obtained for the ETS and BS of accumulated rainfall modelling in periods of six hours, for different thresholds.

\begin{tabular}{lrrr}
\hline Threshold (mm) & 0.1 & 1.0 & 2.5 \\
ETS & 0.25 & 0.23 & 0.19 \\
BS & 1.70 & 1.71 & 1.52 \\
\hline
\end{tabular}

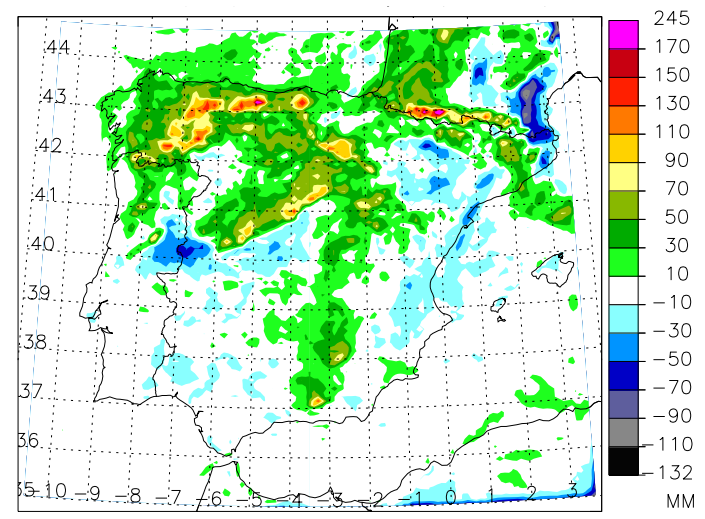

Fig. 4. Accumulated precipitation difference, in mm, from 30 May to 20 June 2002.

The model spatial resolution is higher than that of the observational network, which in addition is irregularly distributed over the area (Fig. 3 on the right). The ETS and BS were calculated for an accumulation period of six hours and three threshold values $(0.1,1.0$ and $2.5 \mathrm{~mm})$. Note that the first threshold value was chosen taking into account the rain gauge resolution, which for all stations is of $0.1 \mathrm{~mm}$. The ETS values shown in Table 1 vary between 0.25 (for a threshold of $0.1 \mathrm{~mm}$ ) and 0.19 (for a threshold of $2.5 \mathrm{~mm}$ ). The BS values range from about 1.7 to 1.5 for the lowest and highest thresholds, respectively. The fact that the BS values are $>1$ confirms the model tendency to overestimate rainfall, at least for the six hour period and the considered thresholds. The decrease of BS with increasing threshold indicates that the overestimation is mostly important for weak precipitation events. The modelled rainfall overestimation was already suggested from the analysis of Fig. 3. The computed scores (Table 1) suggest how MesoNH performances are comparable to other models and reported in literature (Gallus and Segal, 2001; Chien et al., 2002).

\subsection{Statistical analysis of the complete period}

The synoptic situation for the studied period (30 May to 20 June 2002) is characterised by the presence of a thermal low over the Iberian Peninsula, which shows up in the synoptic analysis charts on most of the days. During this period, three distinct polar frontal systems passed over the region (45 June, 7-8 June, and 18-19 June).
Figure 4 shows the accumulated precipitation intensity difference (between the simulation with and without orography) from 30 May to 20 June 2002. Note that the modelled accumulated precipitation distribution for the period is substantially non-homogeneous, with a marked dependence on the orography. An enhancement of the precipitation (positive precipitation difference) is modelled over central and northern Portugal, although slightly negative precipitation differences are distinguished in the region of the Estrela Mountain Range (Centre of Portugal). In addition, positive precipitation differences are delineated over the Cantabrian Mountains, the Central Mountain Range, the Iberian System, the Baetic Mountains, and the Pyrenees. A diminution or even suppression (negative precipitation differences) is attained in the regions south and west of the Central mountain range, the Ebro Valley, the Spanish eastern Mediterranean Coast, and the Roussillon. Note that, as expected, the orographic precipitation enhancement matches the areas over the mountain regions, whereas the diminution is mainly distributed over the shadow regions with low or null relief (Sotillo et al., 2003). Furthermore, the simulations show that the resulting precipitation difference over the southern regions of Portugal and south western Spain is virtually zero. This may indicate that precipitation in these regions is not orographically triggered, which is supported by the fact that these areas are rather low and flat (Fig. 1).

The modelled accumulated precipitation difference is also analyzed in terms of day and night dependence, as shown in Fig. 5, where the upper panel refers to simulations during the day (09:00 to 20:00 UTC) and the lower panel represents the simulations during the night (20:00 to 09:00 UTC). The accumulated precipitation difference pattern distribution on daytime is very similar to that found for the whole period (Fig. 4), only with slightly lower rainfall maxima over the Cantabrian Mountains, Central Mountain Range, Iberian System, Baetic Mountains, and Pyrenees. In contrast, the accumulated precipitation difference during the night presents significant differences with respect to the daytime accumulated precipitation (Fig. 4). In the central sector of Portugal, negative precipitation differences can be noted, as well as in the regions south of the Central Mountain Range and over the eastern Mediterranean coast of Spain. Positive precipitation differences, although with lower values with respect to daytime, are found over the northern portion of the Iberian Peninsula, the Bay of Biscay and the western French coast.

The increase of precipitation over the study area is estimated here as the ratio between the accumulated precipitation difference and the accumulated precipitation simulated without orography, and it is estimated to be $26 \%$ over the $24 \mathrm{~h}$ period. Nevertheless, the increase is rather different for the diurnal and nocturnal periods, being $38 \%$ for the day and $9 \%$ for the night, demonstrating that precipitation, in northern and eastern Iberian Peninsula, is enhanced due to the terrain relief primarily during the day. This difference suggests that, at least for the simulated period, solar heating 

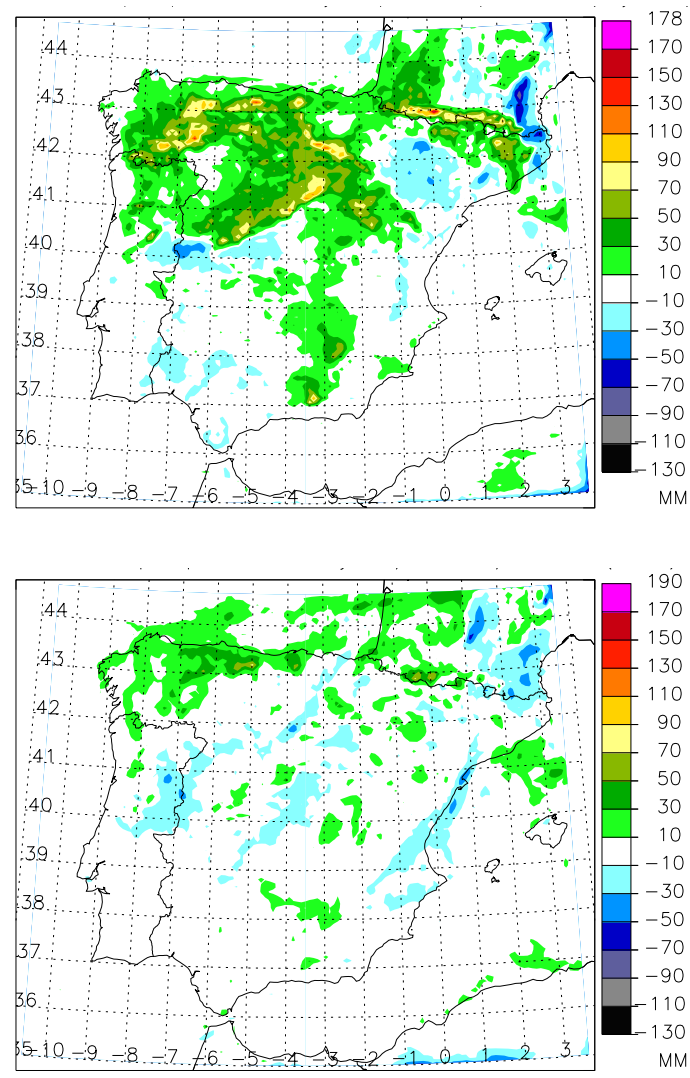

Fig. 5. Accumulated precipitation difference, in mm, from 30 May to 20 June 2002: daytime (upper panel) and nighttime (lower panel).

plays an important role in the orographically triggered convection. In the daytime period, the upward orographic flows across the mountain ranges are enhanced by the upslope valley breeze. Conversely, during the night those flows are reduced by the katabatic downslope winds (Giovannettone and Barros, 2008). The mountain downslope flow is sufficient to decrease or even occasionally inhibit the precipitation over limited areas. In certain synoptic conditions this effect may be responsible for a reduction of total precipitation over the simulation domain.

Figure 6 shows the variation of the spatially accumulated daily precipitation difference during the study period for the geographical domain illustrated in Fig. 1. The accumulated rainfall over the whole domain (in $\mathrm{kg}$ ) is computed multiplying the precipitation at each grid point (in $\mathrm{kg} \mathrm{m}^{-2}$ ) by the area of the grid cell $\left(9 \times 9 \mathrm{~km}^{2}\right)$ and then summing up.

The bar chart shows that, in general, the daytime orographic effects are much more pronounced than those at night time. These results also evidence that precipitation is enhanced due to orography in the majority of the cases. There are, however, a few exceptions that can be distinguished in the graph of Fig. 6: on 10 June the apparent insignificant role of orography is due to the almost total absence of rain over the entire domain; on 3 and 18 June considerable nega-

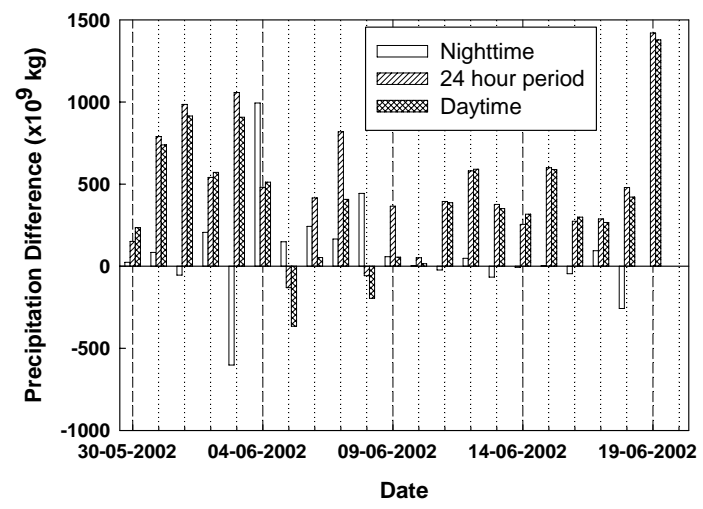

Fig. 6. Variation of the spatially accumulated daily precipitation difference, in $\mathrm{kg}$, during the study period.

tive precipitation differences are registered during the night, which, however, in terms of percentage represent a diminution of less than $30 \%$ in both cases; on 5 and 8 June negative precipitation differences are obtained during the day and for the $24 \mathrm{~h}$ period, nevertheless the percentages are rather small as well, being $<10 \%$ during the day and $<3 \%$ for the $24 \mathrm{~h}$ period, in both cases. On 5 and 8 June the nocturnal precipitation differences exceed those during daytime, and although on 5 June the percentage is very small $(6 \%)$, on 8 June the night time value increases by $171 \%$. This may be connected with the passage of the polar frontal systems, in which cases the amount of precipitation is first determined by the largescale flow and the local effects of orography and thermal circulations are expected to play a relatively minor role.

\section{Summary}

MesoNH modelled precipitation values are qualitatively compared with radar-derived precipitation fields and it is found that in general the model reproduces well the measurements from a visual point of view. The modelled precipitation is also compared with rain gauge data in terms of correlation coefficient, ETS and BS. The correlation coefficient between modelled and observational accumulated rainfall for the whole period is found to be 0.71 , revealing a fairly good agreement between model and observations. The comparisons confirm that MesoNH is a valid tool for model precipitation.

The simulations allowed for obtaining an estimate of orographic precipitation over Iberia, during a limited period. These results show that the orography has an important impact on the spatial distribution of precipitation over the Iberian Peninsula: an enhancement is found over central and northern Portugal, the Cantabrian Mountains, the Central Mountain Range, the Iberian System, the Baetic Mountains, and the Pyrenees. A diminution or even suppression is registered in the regions west of the Central Mountain Range, 
the Spanish eastern Mediterranean Coast, and the Roussillon. The increase of precipitation in the study area due to orography is estimated to be of the order of $1 / 4$. It is also found that precipitation is mainly enhanced during daytime, when apart from the direct effect of orography, thermal circulations may develop (valley breezes), especially in spring and summertime, which intensify vertical velocities and vorticity, contributing to convective rainfall.

It is envisaged to extend the study to more recent years in order to permit the use of radar data purged from ground clutter from the Coruche/Cruz de Leão radar and another one recently installed, which will allow for a quantitative comparison over a wider area. In addition, a comparison of the modelling results with satellite precipitation retrievals is also foreseen in order to extend the study to the surrounding sea and thus gaining an idea on propagation of convective precipitation due to the orography.

Acknowledgements. This work is supported by FCT through grant SFRH/BD/27870/2006 and through project PTDC/CTEATM/65307/2006. VL wishes to recognise partial support from the project AEROCLOUDS of the Italian Ministry of Education, University and Research.

Edited by: S. C. Michaelides

Reviewed by: three anonymous referees

\section{References}

Anthes, R. A.: A review of regional models of the atmosphere in middle latitudes. Mon. Weather. Rev., 111(6), 1306-1335, 1983.

Argence, S., Richard, E., Lambert, D., and Arbogast, P.: Summer precipitation in the Vosges-Black Forest region: Pre-COPS investigations, Meteorol. Atmos. Phys, 103, 105-113, 2009.

Bechtold, P., Bazile, E., Guichard, F., Mascart, P., and Richard, E.: A mass-flux convection scheme for regional and global models, Q. J. Roy. Meteor. Soc., 127, 869-886, 2001.

Bougeault, P. and Lacarrére, P.: Parameterization of orographyinduced turbulence in a mesobeta-scale model, Mon. Weather. Rev., 117, 1872-1890, 1989.

Carbone, R. E. and Tuttle, J. D.: Rainfall occurrence in the U.S. warm season: The diurnal cycle, J. Climate, 21, 4132-4146, 2008.

Carbone, R. E., Tuttle, J. D., Ahijevych, D. A., and Trier, S. B.: Inferences of predictability associated with warm season precipitation episodes, J. Atmos. Sci., 59, 2033-2056, 2002.

Chien, F. C., Kuo, Y. H., and Yang, M. J: Precipitation forecast of MM5 in the Taiwan area during the 1998 Mei-Yu season. Weather Forecast, 17, 739-754, 2002.

Cohard, J. and Pinty, J.: A comprehensive two-moment warm microphysical bulk scheme. II: 2D experiments with a non hydrostatic model, Q. J. Roy. Meteor. Soc., 126, 1843-1859, 2000.

ECMWF: IFS documentation, technical report, Reading, U. K., http://www.ecmwf.int/research/ifsdocs/, last access: 7 July 2009.

Gallus Jr., W. A. and Segal, M.: Impact of improved initialization of mesoscale features on convective system rainfall in 10-km Eta simulations, Weather Forecast, 16, 680-696, 2001.
Giovannettone, J. P. and Barros, A. P.: A remote sensing survey of the role of landform on the organization of orographic precipitation in Central and Southern Mexico. J. Hydrometeorol., 9, 1267-1283, 2008.

Hohenegger, C. and Schär, C.: Atmospheric predictability at synoptic versus cloud-resolving scales, B. Am. Meteorol. Soc., 88, 1783-93, 2007.

Janowiak, J. E., Dagostaro, V. J., Kousky, V. E., and Joyce, R. J.: An examination of precipitation in observations and model forecasts during NAME with emphasis on the diurnal cycle, J. Climate, 20, 1680-1692, 2007.

Keenan, T. D. and Carbone, R. E.: Propagation and diurnal evolution of warm season cloudiness in the Australian and Maritime Continent region, Mon. Weather. Rev., 136, 973-994, 2008.

Lafore, J. P., Stein, J., Asencio, N., Bougeault, P., Ducrocq, V., Duron, J., Fischer, C., Hereil, P., Mascart, P., Pinty, J. P., Redelsperger, J. L., Richard, E., and Vila-Guerau de Arellano, J.: The Meso-NH Atmospheric Simulation System. Part I: Adiabatic formulation and control simulations, Ann. Geophys., 16, 90-109, 1998 , http://www.ann-geophys.net/16/90/1998/.

Laing, A. G., Carbone, R. E., Levizzani, V., and Tuttle, J.: The propagation and diurnal cycles of deep convection in northern tropical Africa, Q. J. Roy. Meteor. Soc., 134, 93-109, 2008.

Levizzani, V., Ginnetti, R., Laing, A. G., and Carbone, R. E.: Warm season precipitation climatology: first European results, Adv. Geosci., 7, 1-4, 2006, http://www.adv-geosci.net/7/1/2006/.

Masson, V.: A physically-based scheme for the urban energy balance in atmospheric models, Bound-Layer Meteor., 94, 357-397, 2000.

Masson, V., Champeaux, J., Chauvin, F., Meriguet, C., and Lacaze, R.: A global database of land surface parameters at 1-km resolution in meteorological and climate models, J. Climate, 16(9), 1261-1282, 2003.

Millán, M. M., Artíñano, B., Alonso, L., Navazo, M., and Castro, M.: The effect of meso-scale flows on regional and long-range atmospheric transport in the western Mediterranean area, Atmos. Environ., 25A, 949-963, 1991.

Millán, M. M., Mantilla, E., Salvador, R., Carratalá, A., Sanz, M. J., Alonso, L., Gangoiti, G., and Navazo, M.: Ozone cycles in the western Mediterranean basin: Interpretation of monitoring data in complex coastal terrain, J. Appl. Meteorol., 39, 487-508, 2000.

Mironov, D. V.: Parameterization of lakes in numerical weather prediction. Description of a lake model. COSMO Technical Report, 11, Deutscher Wetterdienst, Offenbach am Main, Germany, 41 pp., 2008.

Morcrette, J.-J.: Radiation and cloud radiative properties in the European Center for Medium-range Weather Forecasts forecasting system, J. Geophys. Res., 96, 9121-9132, 1991.

Noilhan, J. and Mahfouf, J.-F.: The ISBA land surface parameterization scheme, Global Planet. Change, 13, 145-159, 1996.

Roe, G.: Orographic precipitation, Annu. Rev. Earth Pl. Sc. 33, 645-671, 2005.

Rotunno, R. and Houze, R. A.: Lessons on orographic precipitation from the Mesoscale Alpine Programme, Q. J. Roy. Meteor. Soc., 133, 811-830, 2007.

Salgado, R. and Le Moigne, P.: Coupling of the FLake model to 
the Surfex externalized surface model, Boreal Environ. Res., 15, 231-244, 2010.

Schaefer, J. T.: The critical success index as an indicator of warning skill, Weather. Forecast, 5, 570-575, 1990.

Smith R. B. and Barstad, I.: A linear theory of orographic precipitation, J. Atmos. Sci., 61, 1377-1391, 2004.

Sotillo, M. G., Ramis, C., Romero, R., Alonso, S., and Homar, V.: Role of orography in the spatial distribution of precipitation over the Spanish Mediterranean zone, Clim. Res., 23, 247-261, 2003.
Wang, C.-C., Chen, G. T.-J., and Carbone, R. E.: A climatology of warm-season cloud patterns over East Asia based on GMS infrared brightness temperature observations, Mon. Weather. Rev., 132, 1606-1629, 2004.

Wang, C.-C., Chen, G. T.-J., and Carbone, R. E.: Variability of warm-season cloud episodes over East Asia based on GMS infrared brightness temperature observations, Mon. Weather. Rev., 133, 1478-1500, 2005 